Vol. 1, NO. 2, November 2016

\title{
HUBUNGAN KELENTURAN DAN KELINCAHAN DENGAN KEMAMPUAN DASAR SEPAKSILA PADA SEPAKTAKRAW
}

\author{
Hasriwandi Nur \\ Program Studi Pendidikan Jasmani Kesehatan dan Rekreasi, Fakultas Ilmu Keolahragaan, Universitas \\ Negeri Padang
}

\begin{abstract}
Masalah penelitian ini adalah masih rendahnya kemampuan dasar sepaksila mahasiswa FIK UNP, yang diduga karena kurangnya kelenturan dan kelincahan. Penelitian ini bertujuan untuk mendeskripsikan hubungan antara kelenturan dan kelincahan baik secara sendiri-sendiri maupun bersama-sama dengan kemampuan dasar sepaksila. Populasi penelitian adalah mahasiswa FIK UNP yang mengambil mata kuliah sepaktakraw dasar yang berjumlah 62 orang, terdiri dari 48 putra dan 14 putri. Penarikan sampel dilakukan dengan teknik total sampling. Instrumen yang digunakan adalah : (1) Tes Duduk dan Raih (Sit and Reach Test); (2) Tes lari Berkelok-kelok; (3) Tes mengontrol bola menggunakan kaki bagian dalam untuk mengukur kemampuan dasar sepaksila. Temuan penelitian menunjukkan : (1) Terdapat hubungan yang berarti antara kelenturan dengan kemampuan dasar sepaksila; (2) Terdapat hubungan yang berarti antara kelincahan dengan kemampuan dasar sepaksila; (3) terdapat hubungan yang berarti antara kelenturan dan kelincahan secara bersamasama dengan kemampuan dasar sepaksila.
\end{abstract}

Kata Kunci: Kelenturan, Kelincahan, dan Kemampuan Dasar Sepaksila

\section{PENDAHULUAN}

Indonesia merupakan salah satu negara berkembang yang sedang giat-giatnya melaksanakan pembangunan di segala bidang. Salah satu bidang yang tidak kalah penting adalah pembangunan dalam bidang olahraga.

Olahraga kini telah mengalami kemajuan yang sangat pesat dimana saat ini olahraga telah memasuki semua aspek kehidupan seperti industri, perekonomian, pendidikan dan lain sebagainya.

Hal ini sesuai dengan Undang-Undang Republik Indonesia No.3 Tahun 2005 Tentang Sistem Keolahragaan Nasional Pasal 4 yang menyatakan bahwa keolahragaan nasional bertujuan untuk memelihara dan meningkatkan kesegaran dan kebugaran jasmani, prestasi, kualitas manusia, menanamkan nilai moral dan akhlak mulia, sportivitas, disiplin, mempererat dan membina persatuan dan kesatuan bangsa, memperkukuh ketahanan nasional, serta mengangkat harkat, martabat, dan kehormatan bangsa.

Berdasarkan kutipan di atas, dapat diketahui bahwa salah satu tujuan yang ingin dicapai oleh bangsa Indonesia adalah memelihara dan meningkatkan prestasiprestasi di berbagai cabang olahraga. Selain itu, tercapainya tujuan keolahragaan nasional yaitu menumbuhkan generasi yang sehat jasmani maupun rohani, memiliki kebugaran jasmani, berkualitas, bermoral dan akhlak mulia, sportif, dan disiplin yang nantinya diharapkan akan berdampak positif terhadap pembangunan nasional di bidang-bidang lainnya.

Agar hal tersebut dapat terwujud, maka dibutuhkan sekali kerjasama antara semua pihak baik pemerintah, insan olahraga maupun masyarakat. Dari berbagai jenis olahraga yang cukup memasyarakat saat ini salah satunya adalah sepaktaraw.

Sepaktaraw mempunyai arti yang sangat penting yaitu merupakan salah satu olahraga yang harus dikembangkan dan dilestarikan, sehingga kebudayaan bangsa Indonesia dapat terjaga dengan baik

Permainan sepaktaraw salah satu cabang olahraga yang cukup populer sampai saat ini di Indonesia khususnya Sumatera 
Barat. Sepaktaraw telah banyak mengalami perubahan dan perkembangan dari berbagai bentuk baik peraturan maupun permainannya yang digemari oleh seluruh lapisan masyarakat. Kemajuan Ilmu Pengatahuan dan Teknologi yang sangat pesat banyak mempengaruhi perkembangan sepaktaraw tersebut.

Sepaktaraw merupakan permainan yang membutuhkan banyak energi, kepintaran di dalam lapangan memacu semangat, sekaligus memberikan kegembiraan melalui kebersamaan dalam sebuah tim.

Apabila kita berbicara tentang prestasi sepaktaraw, maka tuntutan keterampilan teknik tinggi sangat diperlukan oleh pemain-pemain sepaktaraw. Untuk mencapai semua itu diperlukan kondisi fisik yang prima dari atlit. Seiring perkembangan dari segala bidang tentang sepaktaraw, maka dirasa perlu mahasiswa mengikuti kemajuan perkembangan cabnag sepaktaraw.

Mahasiswa diposisikan sebagai sumber mahasiswa potensial, berfungsi sebagai penyangga untuk berprestasi tingkat nasional. Sementara itu, prestasi sepaktaraw dalam dimensi latihan adalah akumulasi keterampilan (skill) hasil latihan fisik, taktik, teknik dan mental, berdasarkan uraian di atas maka peneliti menetapkan aspek psikologis (mental) dan juga motivasi latihan para mahasiswa sebagai ruang lingkup kajian penelitian, alasanya sesempurna apapun fisik, teknik dan taktik bila mental mahasiswa tidak berkembang prestasi tinggi tidak mungkin akan dapat dicapai.

Salah satu kemampuan dasar dalam permainan sepaktakraw adalah sepaksila. Sepaksila adalah menyepak bola dengan menggunakan kaki bagian dalam. Dinamakan dengan sepaksila karena sikap kaki disaat menyepak terlihat seperti bersila. Disini akan bekerja persendian dan otot-otot di daerah pinggang, pinggul, paha dan tungkai bawah, sedangkan anggota tubuh bagian atas hanya berfungsi sebagai pendukung.
Salah satu unsur kondisi fisik yang diperlukan dalam sepaksila adalah kelenturan dan kelincahan. Kelenturan menyangkut luas jarak gerak atau jangkauan gerak persendian. Sedangkan kelincahan adalah kemampuan untuk berpindah arah dalam waktu yang secepat mungkin.

Dalam melakukan sepaksila, kelenturan dan kelincahan diperlukan dalam melakukan gerakan sepaksila agar gerakan dan arah bola yang dihasilkan baik sehingga serangan yang dihasilkan dalam permainan sepaktakraw menjadi lebih baik.

Dalam permainan sepaktakraw ada 2 macam kategori kemampuan yang harus di miliki oleh pemain, yaitu kemampuan dasar atau teknik dasar dan kemampuan khusus atau teknik khusus.

Kemampuan dasar adalah komponen mendasar dalam permainan sepak takraw. Karena terkait dengan aktivitas gerak dasar permainan itu sendiri. Sebagai contoh permainan sepak takraw banyak menggunakan sepakan. Karena peraturan melarang menggunakan tangan, maka yang menjadi contoh komponen dasar disini adalah berbagai sepakan.

Adapun kemampuan khusus atau teknik khusus dalam permainan sepak takraw adalah karakter/ciri permainan sepak takraw, dimana dalam permainan sepak takraw mengandung unsur penyerangan dan pertahanan menurut Darwis (1992 : 60) pengertian teknik khusus dalam permainan sepaktakraw adalah cara bermain sepaktakraw "bagaimana permainan dimulai, setelah permainan di mulai apa yang di lakukan setelah bola di kuasai tindakan apa yang harus dilakukan untuk membuat penyerangan sehingga mendapatkan angka bagi regunya . bila bola dikuasai lawan apa usaha yang akan dilakukan agar lawan tidak memperoleh angka.

Selanjutnya yang akan dikaji adalah yang berkaitan dengan kemampuan dasar. Untuk dapat melakukan permainan sepaktakraw dengan baik, seseorang di tuntut memiliki kemampuan yang baik. 
Kemampuan yang di maksud adalah kemampuan dasar bermain sepaktakraw. Selanjutnya Darwis (1992:15) menyatakan “ kemampuan yang penting dalam bermain sepaktakraw adalah kemampuan dasar bermain sepaktakraw. Bila seseorang tidak mempunyai kemampuan tersebut tidak akan bisa bermain sepaktakraw".

Berbagai kemampuan dasar sepaktakraw atau sebagian ahli menyebut juga dengan teknik dasar adalah : menyepak dengan menggunakan bagian-bagian kaki memainkan bola dengan kepala, dada, paha, bahu dan dengan telapak kaki.

Teknik dasar akan dimiliki dengan baik , bila berlatih dengan benar dan kontinyu, dalam hal ini prestasi sepaktakraw tidak saja di tentukan oleh penguasaan teknik dasar, tetapi berbagai faktor seperti kondisi fisik, psikis, dan lainnya akan banyak menunjang

Menurut PB Persetasi (1999:4) dalam permainan sepaktakraw menyepak merupakan gerakan yang dominan. "dapat dikatakan bahwa keterampilan menyepak itu merupakan ibu dari permainan sepaktakraw karena bola di mainkan dengan kaki, mulai dari permulaan permainan sampai membuat angka, salah satu dari kemampuan dasar atau teknik dasar menyepak tersebut adalah sepak sila".

Pengertian sepak sila menurut PB Persetasi (1999:4) adalah "menyepak bola dengan menggunakan kaki bagian dalam". Dinamakan dengan sepaksila karena sikap kaki disaat menyepak terlihat seperti bersila. Disini akan bekerja persendian dan otot-otot di daerah pinggang, pinggul, paha dan tungkai bawah, sedangkan anggota tubuh bagian atas hanya berfungsi sebagai pendukung.

Pada saat melakukan sepaksila terjadi tarikan otot yang melintang di daerah pinggul ke pangkal paha untuk menarik sendi pinggul dan pangkal paha kearah abduksi., disini akan bekerja otot di daerah paha.

Untuk mengayun kaki sepak, akan bekerja aktif paling tidak otot paha bagian belakang (hamstring) untuk melakukan gerak fleksi terhadap lutut dan disini bekerja sama dengan otot paha bagian depan (kuadricep) untuk melakukan gerak ekstensi yang bekerja sinergis dengan hamstring dalam melakukan kontraksi otot. Makin baik kelenturan otot di daerah ini, akan menjadi penentu dalam melakukan sepak sila.

Depdiknas (2002:16) menyatakan kelenturan adalah "kemampuan untuk mengunakan lebar ayunan gerakan dalam persendian ke kemampuan maksimum".

Menurut Alter (2003:3) "kelenturan adalah kemampuan untuk mengerakkan otot beserta persendian pada seluruh daerah pergerakan". Adapaun Baumgartner dan Jackson (1982:208) menyatakan "flexibility is the range of movement about a joint" artinya kelenturan adalah jangkauan gerak di sekitar sendi. Demikian juga Barrow dan Mc Gree dalam Kirkendall (1980:248) mendefinisikan kelenturan sebagai "the range of movement in a joint".

Fox dan Mathews (1971:166) menyatakan "the range of motion about a joint is defined as static flexibility" yang artinya jangkauan gerak di sekitar suatu sendi didefinisikan sebagai kelenturan statis.

Kemudian Fox juga mengemukakan pengertian kelenturan dinamis sebagai "the opposition or resistance of a joint to motion in other words, it is concerned with the forces that oppose movement over any range rather than the range its self' pengertiannya perlawanan atau kekuatan melawan jangkauan gerak sebuah sendi. Dengan kata lain kelenturan ini mengenai kekuatan melawan gerak melebihi sesuatu jarak dari pada jarak itu sendiri.

Dari beberapa pendapat di atas, mengemukaka definisi yang sama tentang kelenturan. Dimana kelenturan menyangkut luas jarak gerak atau jangkauan gerak persendian. Baumgartner dan Barrow memakai istilah movement, sedangkan Fox memakai kata motion untuk gerak.

Menurut Sukintaka (2004:78) "movement menpunyai pengertian gerak lahiriah yang dapat diamati, dan ia 
mementingkan ketepatan. Sedangkan motion menurut Bun dalam Sukintaka merupakan unsur penting dalam olahraga, yang di dalamnya mengandung perlawanan terhadap usaha pada waktu melakukan gerakan".

Fox (1971:166) membagi kelenturan menjadi 2 macam, yaitu statis dan dinamis. Selanjutnya Fox meyatakan bahwa kelenturan statis dapat diukur paling dapat dipercaya dengan suatu instrument yang dinamakan flexometer.

Dinamakan dengan kelenturan statis karena ketika pembacaan angka pada flexometer, tidak dibolehka lagi persendian bergerak.Sedangkan kelenturan dinamis menurut Fox lebih sulit untuk diukur.

Bompa (1983) menyatakan 2 tipe kelenturan, yaitu umum dan kusus. Pengertian ini menurut sudut pandang metodologi latihan kelenturan umum berkaitan dengan fakta yang dimiliki atlet dengan mobilitas yang bagus dari seluruh persendian tubuhnya dan terlepas dari yang dipersyaratkan secara khusus dalam cabang olahraga.

Sedangkan kelenturan khusus menunjukkan kualitas olahraga yang mana atau khusus sendi yang mana. Kirkendal (1980:243) mendefinisikan "kelincahan sebagai kemampuan merobah arah dari tubuh atau bagian tubuh secara cepat".

$$
\text { Phillips dan Hornak (1979:61) }
$$

mendefinisikan "kelincahan sebagai kemampuan merobah arah secara cepat dan akurat”. Baumgartner dan Jackson (1982:203) menyatakan "agility is the ability to change the direction of the body or body part rapidlay" artinya kelincahan adalah kemampuaan merubah arah dari tubuh atau bagian tubuh dengan cepat.

Sedangkan Suharno (1985:32)

mengemungkakan: "kelincahan adalah kemampuan untuk merubah posisi dan arah secepat mungkin sesuai dengan situasi yang di hadapi dan dikehendaki".

Wahjoedi (2001:61) menyatakan "kelincahan adalah kemampuan tubuh untuk mengubah arah secara cepat tanpa ada gangguan keseimbangan atau kehilangan keseimbangan". Depdiknas (2002:62) menyamakan kelincahan dengan kemampuan untuk mengubah arah tubuh secara cepat sambil bergerak.

Dari berbagai pendapat difinisi kelincahan di atas, dapat ditarik suatu pengertian bahwa kelincahan adalah kemampuan mengubah arah dari tubuh atau bagian tubuh dengan cepat dan tepat.

Dikatakan mengubah arah, karena kelincahan bukan kemampuan satu arah seperti sprint. Disini terkait dengan kecepatan gerak.Dikatakan bagian tubuh, karena mungkin bagian tubuh atau otot-otot tertentu yang dominan saja berkerja seperti: paha, pinggul, pinggang

Demikian juga dikatakan dengan cepat dan tepat, karena alat ukur penampilan dalam satuan waktu. Kata tepat berarti bahwa kelinchan bukan hanya sekedar cepat saja, tetapi sesuai dengan situasi yang di hadapi dan dikehendaki tanpa gangguan keseimbangan.

Dengan gerak, tubuh manusia dapat berpindah tempat apakah gerakannya berulang kali atau sekali saja, apakah seluruh tubuh atau bagian tubuh tertentu, yang terpenting untuk maksud apa gerak tersebut dilakukan.

Maka hakekat kualitas kelincahan gerak dalam keterampilan berolahraga atau pendidikan jasmani atau dalam kehidupan adalah cepat dan tepatnya gerak tubuh atau bagian tubuh tersebut berubah arah dan berubah posisi.

Phillips dan hornak (1979:242) menyatakan "kelincahan biasanya merupakan salah satu komponen yang betul-betul dipertimbangkan dalam kemampuan gerak umum (general motor ability) dan kebugaran gerak (motor fitness) dan ,oleh karenanya kebanyakan baterai tes pengukuran motor ability dan fitness paling tidak termasuk satu item kelincahan"

Hal ini dapat di contohkan, bahwa dalam item tes kempuan gerak Barrow yang terdiri dari: lompat jauh tanpa awalan, melempar bola, passing ke dinding, menolak bola 
medicine, lari berkelok kelok, dan lari cepat 60 yard di dalamnya terdapat satu item kelincahan yaitu lari berkelok - kelok ( zig- zag run) yang bertujuan untuk mengukur kelincahan gerak.

Bila dilihat posisi kelincahan dalam kebugaran gerak (motor fitness), maka salah satu komponen yang dites di dalamnya adalah kelincahan.

Sesuai dengan Clark dalam Baumgartner (1982 :277) “ bahwa 7 (tujuh) komponen yang didefinisikan sebagai motor fitness dan tes yang sering digunakan untuk mengukur kemampuan tersebut terdiri dari : kekuatan otot, daya tahan otot, daya tahan jantung- paru, tenaga otot, kelincahan, kecepatan, dan kelenturan. Disini jelas termasuk di dalamnya komponen kelincahan.

Kelincahan juga terpakai di dalam kebugaran jasmani yang berkaitan dengan keterampilan gerak. Hal ini dikemukakan oleh Wahjoedi (2001), bahwa ada dua bentuk kebugaran jasmani, yaitu kebugaran jasmani berhubungan dengan kesehatan ( health related fitness), meliputi: daya tahan jantung - paru, daya tahan otot, kekuatan otot, kelenturan, dan komposisi tubuh.

Sedangkan kebugaran jasmani yang berkaitan dengan keterampilan gerak (skill related fitness) meliputi: kecepatan, kecepatan reaksi, daya ledak, kelincahan, keseimbangan , ketepatan dan koordinasi.

Begitu berperannya kelincahan ini di dalam komponen kondisi fisik selain digunakan sebagai komponen general motor ability, motor fitness, dan skill related fitness, kelincahan juga dipakai sebagai alat peramal keberhasilan aktivitas pendidikan jasmani dan olahraga.

Dalam belajar praktek sepaksila, mahasiswa yang telah memiliki modal kondisi kelincahan akan lebih cepat berhasil dibandingkan mahasiswa yang kurang memiliki kelincahan. Hal ini karena kesempatan berlatih atau frekuensi menyepak lebih banyak dilakukan oleh mahasiswa yang lincah.
Orang yang lincah, ketika hasil sepakannya melenceng akan bereaksi dan bergerak dengan cepat kearah bola, sehingga bola dapat dikontrol kembali. Sementara mahasiswa yang tidak memiliki modal kelincahan, waktunya akan habis untuk mengambil bola saja.

Reaksi bergerak cepat diperlukan dalam permainan sepaktakraw. Depdiknas (2002:6) menyatakan '"komponen antisipasi dan akselerasi juga sangat dibutuhkan oleh para pemain sepaktakraw, terutama untuk mendeteksi arah datangnya bola dari lawan dan harus bergerak cepat (akselerasi) untuk melakukan gerakan reaksi/balasan". Berdasarkan kutipan ini, bereaksi dan bergerak cepat merupakan komponen kondisi kelincahan.

Kondisi kelincahan dapat ditingkatkan dengan melatih komponen-kompoenen lain yang terkait dengan kelincahan. Phillips dan Hornak (1979:242) menyatakan "walaupun penelitian menunjukkan bahwa kelincahan sedikit tergantung pada keturunan, namun kelincahan dapat ditingkatkan dengan praktek, latihan dan pengajaran karena waktu reaksi,waktu bergerak, dan koordinasi otot-otot besar adalah aspek penting, dengan praktek dan latihan aktivitas ini akan meningkatkan kelincahan.

Maksud kelincahan sedikit tergantung pada keturunan diatas adalah karena kelincahan terkait dengan otot. Menurut Fox (1984) kontraksi otot dipengaruhi oleh serabut otot.

Manusia memiliki dua macam serabut otot, yaitu serabut otot lambat (slow twitch) dan serabut otot cepat (fast twitch). Orang yang memiliki serabut otot cepat lebih banyak, akan memiliki kelincahan yang lebih tinggi dibanding yang memiliki serabut otot lambatnya banyak. Serabut otot cepat ini berasal dari keturunan, bukan faktor latihan.

Dalam sepaksila, otot yang banyak terlibat adalah otot-otot daerah tungkai bawah. Dengan memiliki kondisi kelincahan akan lebih efisien mengatur otot tungkai ini. 
Demikian juga otot tungkai perlu kuat, agar mampu menahan berat badan yang berdiri dengan satu kaki tumpu ketika gerakan menimbang-nimbang bola, serta tenaga otot tungkai juga penting untung melakukan sepakan tersebut.

Berdiri dengan satu kaki tumpu menimbang bola dengan sepaksila, yang menuntut secara teknik kaki sepak bagian dalam minimal setinggi lutut dan kaki berayun dari bawah ke atas untuk memukul bola, juga membutuhkan kondisi keseimbangan.

Depdiknas (2002:7) menyatakan. "komponen keseimbangan diperlukan oleh pemain sepaktakraw terutama saat melakukan servis, mengumpan dan smash" disini. Gerakan mengumpan tentu dilakukan dengan menggunakan sepak sila.

Begitu pentingnya kelincahan ini dalam permainan sepaktakraw, sehingga dalam bagian profil keberbakatan cabang olahraga, yang terdiri dari 41 cabang olahraga termasuk salah satunya sepaktakraw. Pada komponen lari kelincahan untuk sepaktakraw, dipersyaratkan dengan angka 5 yang berarti sangat penting (Depdiknas 2002).

\section{METODE PENELITIAN}

Penelitian tergolong pada jenis penelitian korelasional dengan menggunakan teknik expost facto. Penelitian expost facto merupakan penelitian yang bertujuan menemukan penyebab yang memungkinkan perubahan perilaku, gejala atau fenomena yang disebabkan oleh suatu peristiwa, perilaku atau hal-hal yang menyebabkan perubahan pada variable bebas yang secara keseluruhan sudah terjadi.

Populasi penelitian ini adalah mahasiswa Jurusan Pendidikan Olahraga FIK UNP yang mengikuti Mata Kuliah Sepaktakraw. Pengambilan sampel dilakukan dengan teknik random sampling, sehingga sampel yang diambil berjumlah 62 orang.

Kemampuan sepaksila diukur dengan tes mengontrol bola sepaktakraw, kelincahan dengan zig-zag run, dan kelenturan dengan sit and reach. Teknik analisis data yang digunakan adalah teknik analisis korelasi sederhana dan ganda. Hipotesis 1, dan 2 dianalisis dengan korelasi dan regresi sederhana, sedangkan hipotesis 3 dianalisis dengan korelasi dan regresi ganda.

\section{HASIL DAN DISKUSI}

Berdasarkan analisis yang dilakukan pada pengujian hipotesis I yaitu terdapat hubungan yang signifikan kelenturan dengan kemampuan sepaksila, dan kontribusinya sebesar $59.3 \%$ antara kelenturan terhadap kemampuan dasar sepaksila. Kelenturan merupakan salah satu kompoenen fisik yang telah terbukti hubungannya dengan kemampuan dasar sepaksila.

Hal ini sesuai dengan Fox (1987:224) bahwa "kelenturan optimal telah ditunjukkan melalui penelitian, banyak manfaat yang berarti, kelenturan tidak hanya mempertinggi kemampuan kita untuk melakukan keterampilan tertentu tetapi juga. Berdasarkan kutipan di atas, sepaksila termasuk suatu keterampilan, dan relatif sulit dipelajari. Suatu keterampilan tidak hanya menuntut latihan yang tekun dan serius, tetapi untuk mempertinggi kemampuan keterampilan seperti sepaksila sangat menuntut kelenturan tubuh.

Sepaksila dilakukan pada ruang gerak. yang sempit, yaitu bola disepak dekat dari tubuh diantara kedua kaki dan arah ayunan kaki dari bawah serta perkenaan kaki dengan bola harus pada kaki bagian dalam (di bawah mata kaki).

Dalam hal ini sangat dituntut kelenturan sendi dan otot khusus yang berperan utama dalam gerakan menyepak. Sendi dan otot khusus yang dominan disini diantaranya adaiah sendi putar pinggul dan pangkal paha, otot-otot paha, pinggul, pinggang, pantat dan lainnya. Sedangkan bagian tubuh atas hanya berfungsi sebagai penunjang.

Bila seseorang memiliki kelenturan yang baik pada daerah sendi dan otot tersebut, akan membuat gerakan tungkai lebih luas menyepak pada ruang gerak yang sempit tanpa 
adanya hambatan gerak atau gerak yang tertahan dan pada akhirnya, akan membuat hasil kemampuan dasar sepaksilanya lebih baik. Sebaliknya, apabila seseorang memiliki tingkat kelenturan yang terbatas/tertahan, tentu akan menghalangi gerakan ayunan tungkai dan daya tahannya, karena otot-otot harus berkerja keras untuk mengatasi tahanan dalam melakukan tugas gerakan menyepak. Serta hal ini akan membuat hasil sepaksilanya rendah atau kurang.

Terbatasnya kelenturan akan berakibat terjadinya berbagai kekurangan -kekurangan dalam belajar keterampilan. Sehubungan dengan ini, Pectl dalam Bompa (1983 : 322) menyatakan :

"Suatu pengembangan kelenturan yang tidak cukup atau tidak memiliki cadangan kelenturan akan berakibat kekurangan terhadap : (a) belajar, karena kesempurnaan gerakan tergantung; (b) mudah cidera; (c) pengembangan kekuatan, kecepatan dan koordinasi tergantung; (d) mutu penampilan gerakan terbatas atau bila seseorang memiliki cadangan kelenturan, keterampilan akan dilakukan dengan lebih banyak, lebih cepat, dengan semangat, dengan mudah dan perasaan".

Berdasarkan kutipan diatas, banyak kekurangan-kekurangan yang terjadi terhadap belajar dan berlatih keterampilan, bila seseorang tidak memiliki cukup kelenturan, kecepatan dan koordinasi. Sebaliknya, melatih kelenturan akan membantu terhadap kekuatan, kecepatan dan koordinasi.

Dapat dicontohkan, dengan latihan kelenturan balistik menggunakan bola medicine, terdapat sekaligus latihan kekuatan kecepatan dan koordinasi di dalamnya.

Latihan kelenturan tidak akan berlawanan atau berdampak negatif terhadap kekuatan. Disini akan tergantung kepada tujuan dari latihan. Tujuan utama latihan kekuatan adalah otot-otot yang representatif sedangkan tujuan akhirnya adalah seberapa banyak serabut otot yang dapat diregang. Dengan demikian kedua bentuk latihan tersebut sama-sama meregang otot.

Mengingat pentingnya kelenturan yang baik untuk meningkatkan kemampuan dasar sepaksila, maka timbul pertanyaan : " usaha apa yang dapat dilakukan untuk meningkatkan kemampuan dasar sepaksila mahasiswa?". Usaha untuk meningkatkan kemampuan dasar sepaksila mahasiswa adalah dengan meningkatkan mutu proses dan hasil perkuliahan sepak takraw dasar itu sendiri.

Dalam hal ini, dosen yang mengajarkan sepak takraw dasar dituntut untuk memberikan penekanan khusus pada mahasiswa tentang kelenturan, baik kelenturan umum, apalagi khusus yang berkaitan dengan sepaksila.

Berdasarkan analisis yang dilakukan pada pengujian hipotesis II yaitu terdapat hubungan kelincahan dengan kemampuan sepaksila, dan $24 \%$ kelincahan berkontribusi terhadap kemampuan dasar sepaksila.

Kelincahan adalah kemampuan mengubah arah dari tubuh atau bagian tubuh dengan cepat dan tepat. Dikatakan mengubah arah, karena kelincahan bukan kemampuan satu arah seperti sprint. Disini terkait dengan kecepatan gerak.Dikatakan bagian tubuh, karena mungkin bagian tubuh atau otot-otot tertentu yang dominan saja berkerja seperti: paha, pinggul, pinggang.

Demikian juga dikatakan dengan cepat dan tepat, karena alat ukur penampilan dalam satuan waktu. Kata tepat berarti bahwa kelinchan bukan hanya sekedar cepat saja, tetapi sesuai dengan situasi yang di hadapi dan dikehendaki tanpa gangguan keseimbangan.

Dengan gerak, tubuh manusia dapat berpindah tempat apakah gerakannya berulang kali atau sekali saja, apakah seluruh tubuh atau bagian tubuh tertentu, yang terpenting untuk maksud apa gerak tersebut dilakukan. Maka hakekat kualitas kelincahan gerak dalam keterampilan berolahraga atau pendidikan jasmani atau dalam kehidupan adalah cepat dan tepatnya gerak tubuh atau bagian tubuh tersebut berubah arah dan berubah posisi. 
Berdasarkan analisis yang dilakukan pada pengujian hipotesis III yaitu terdapat hubungan antara antara kelenturan dan kelincahan dengan kemampuan dasar sepaksila. Harga koefisien korelasi ganda $\mathrm{R}$ sebesar 0,81 dapat diinterpretasikan sebagai hubungan yang kuat atau tinggi.

Sedangkan harga koefisien determinasi sebesar 0,66 berarti bahwa $66 \%$ kelenturan dan kelincahan secara bersama-sama berkontribusi terhadap kemampuan dasar sepaksila, atau $66 \%$ varians kemampuan dasar sepaksila sebagai variabel terikat dapat dijelaskan secara bersama-sama oleh variabel bebas kelenturan dan kelincahan.

Kedua variabel bebas tersebut yaitu kelincahan dan kelenturan, apabila dimaksimalkan masing-masing fungsinya maka pasti akan memperoleh kontribusi yang sangat baik terutama kemampuan sepkasila dalam sepaktakraw.

Hal ini karena dalam penelitian ini kemampuan sepaksila dipengaruhi oleh faktor kelenturan dan kelincahan. Kelenturan dapat ditingkatkan dengan cara melatihnya sesuai dengan latihan yang terencana, sistematis dan terukur, dimana kelenturan merupakan elemen kondisi fisik yang relatif dapat dilatih dan ditingkatkan.

Begitupun kelincahan juga memberikan kontribusi, sehingga kelicahan juga harus ditingkatkan dengan cara melatihnya sesuai dengan latihan yang terencana, sistematis dan terukur.

\section{KESIMPULAN}

Berdasarkan temuan penelitian dan pembahasan hasil penelitian maka dapat disimpulkan sebagai berikut:

1. Kelenturan memiliki hubungan yang signifikan dengan kemampuan sepaksila, dimana $t_{\text {hitung }}(9.3)>t_{\text {tabel }}(2.00)$. Kontribusi kelenturan terhadap kemampuan sepaksila sebesar $59.3 \%$.

2. Kelincahan memiliki hubungan yang signifikan dengan kemampuan sepaksila, dimana $t_{\text {hitung }}$ (4.36) $>\mathrm{t}_{\text {tabel }}$ (2.00).
Kontribusi kelincahan terhadap kemampuan sepaksila sebesar $24 \%$.

3. Kelenuturan dan kelincahan secara bersama-sama memiliki hubungan yang signifikan dengan kemampuan sepaksila, dimana $F_{\text {hitung }}$ (56.3) $>F_{\text {tabel }}$ (3.16). Kontribusi kelenturan dan kelincahan terhadap kemampuan sepaksila sebesar $66 \%$.

\section{SARAN}

Berdasarkan hasil penelitian, dikemukakan saran sebagai berikut:

1. Bagi pelatih dan dosen, untuk meningkatkan kemampuan sepaksila atlit maupun mahasiswa dengan cara merencanakan latihan untuk meningkatkan kemampuan sepaksila.

2. Bagi pelatih dan dosen, untuk meningkatkan kemampuan sepaksila atlit maupun mahasiswa dengan cara merencanakan program latihan untuk meningkatkan kelenturan dan kelincahan yang baik dan benar.

3. Kepada atlit dan mahasiswa, untuk memperhatikan kelenturan dan kelincahan untuk meningkatkan kemampuan sepaksila dalam sepaktakraw.

\section{DAFTAR RUJUKAN}

Arikunto, Suharsimi. 2011. Prosedur Penelitan. Jakarta: Renika Cipta

Daniel Goleman. 1999. "Emotional Intelegence". Jakarta:PT Gramedia.

Grace kathrin, Santoso. .2007. Daya Juang Anak Panti Asuhan Usia Remaja Di Vincentius Putri. Penelitian Tidak Diterbitkan :Universitas Katolik Indonesia Atma Jaya Jakarta.

Rusli Luthan. 1998. "Belajar Ketrampilan Motorik, Pengantar Teori dan Methode". Jakarta: Departemen Pendidikan dan Kebudayaan.

Harsono. 1988. "Coaching dan Aspek-Aspek Psikologis Dalam Coaching". 
Jakarta: P2LPTK, Departemen Pendidikan Nasional.

J.S. Zain Badudu Mohammad Sutan. 1994." Kamus Umum Bahasa Indonesia". Jakarta: Pustaka Sinar Harapan.

O. Tudor Bompa. 1983. " Theory and Methodologi of Trainning". Dubuque Iowa: Kendal / Hunt Publishing Company.

Sudjana. 1996. Metode Statistika. Bandung: Tarsito

Zalfendi, dkk. 2002. Pembinaan dan Pengajaran Permainan Sepaktakraw. Padang: FIK UNP 